\title{
GENERATIONAL ACCOUNTING: A COMPARISON BETWEEN VARIOUS TAXES' INCIDENCE ON THE YOUNG AND OLD IN SOUTH AFRICA
}

\author{
J H van Heerden and N J Schoeman ${ }^{*}$
}

\section{Abstract}

This article focuses on the applicability of intergenerational accounting to contribute towards more effective fiscal policy for the correction of wealth imbalances in South Africa. Three scenarios are tested using a general equilibrium model with overlapping generations. An increase in the tax on capital income has a positive effect on the distribution of personal wealth between rich and poor, but it decreases total production.

An estate tax improves the current distribution of wealth with much more positive results. Both total consumption and the total capital stock increase. The welfare position of the rich is largely unaffected while that of the poor increases substantially.

Lastly, it is shown that an increase in indirect taxes produces negative results. The welfare of the poorer group decreases and at the same time there is a decline in the general level of welfare due to lower levels of production and consumption in the economy.

\section{Introduction}

The concept generational accounting developed by Lawrence Kotlikoff and his associates (Auerbach, Gokhale and Kotlikoff, 1994:73) allows one to measure the tremendous cost of short-termism, in politics. The latter is of specific importance to economies in transition and emerging economies such as South Africa. The ever-increasing cost of social security necessitates the reorganisation of the government's budget to portray more transparently, how the burden of paying for government programs is distributed among present and future generations.

Also, in a country such as South Africa where productivity is extremely low and unemployment of the highest in the world, imposing high lifetime net tax burdens on future generations may further depress incentives to work, save and invest

\footnotetext{
"Department of Economics, University of Pretoria, Pretoria 0001, Republic of South Africa. Email: ivheerde@hakuna.up.ac.za and njschoem@hakuna.up.ac.za
} 
thereby sabotaging future growth and prosperity. Thus it is argued that the implementation of generally more neutral policies - policies that do not imply intergenerational redistribution - could be a useful strategy in avoiding significant intergenerational redistribution in the future if such non-uniform growth occurs.

In this paper a general equilibrium model with eleven overlapping generations in each period is developed for three consumer groups. Each group consumes one commodity, which is produced competitively using two factors of production. Simulations are done with South African data to test the effects on the different generations under various tax policy options.

Most tax incidence studies fall in one of two categories (Fullerton and Rogers: 1993: 3). The first is annual incidence studies, which sort individuals into groups according to their annual income, and then study the redistribution effects of taxes among the income groups. The second is life-cycle studies that group people together in different age groups, and then calculate redistribution among the age groups. Figure 1 is taken from Fullerton and Rogers (1993:3). It can be used to demonstrate the problems one may encounter by using only one of the two methods.

Suppose that only two types of individuals are included in the economy, one more affluent than the other. One group advances with age through points A, B, C, and $\mathrm{D}$, while the more affluent group advances through points $\mathrm{E}, \mathrm{F}, \mathrm{G}$, and $\mathrm{H}$. Annual Income is depicted on the vertical axis in Figure 1, and Age on the horizontal.

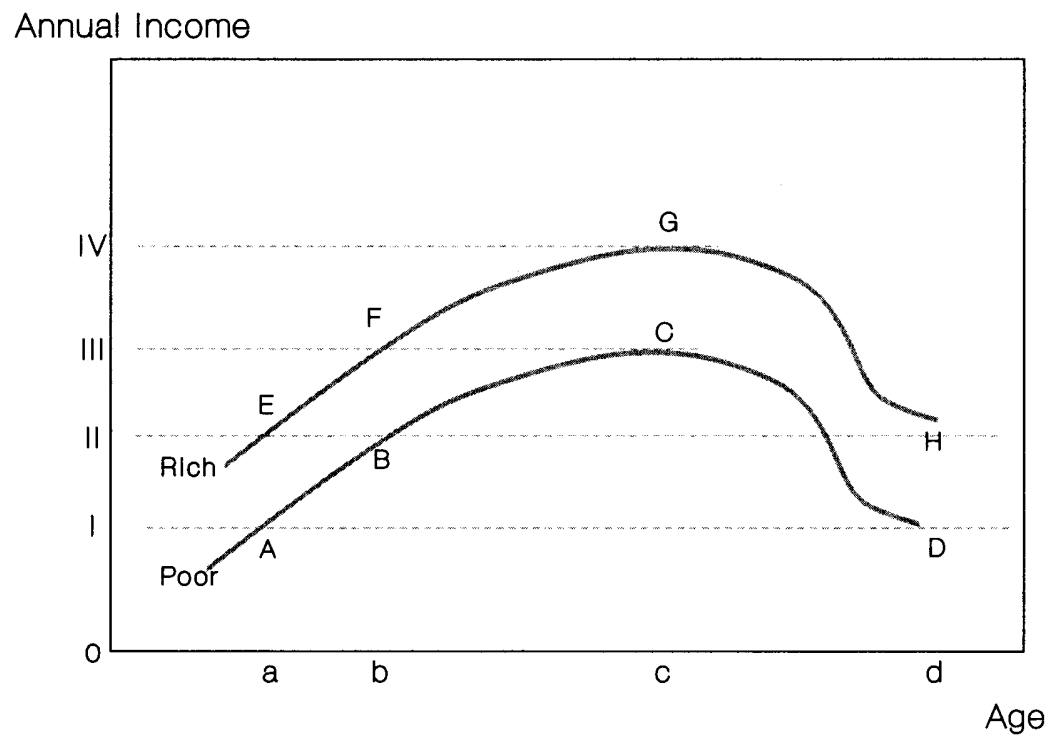

Figure 1: Two lifetime earnings profiles

An annual income study would typically take individuals from the four income levels, I, II, III, and IV, depicted in the figure, group them together, and study redistribution among the groups. They clearly might come from various stages in 
their lifetime: a rich young person $(\mathrm{F})$ might be grouped together with a poor middle aged person $(\mathrm{C})$ reaching his peak income.

"The typical life-cycle study would lump together individuals at points $\mathrm{A}$ and $\mathrm{E}$ as the youngest group, those at $\mathrm{B}$ and $\mathrm{F}$ as another group, $\mathrm{C}$ and $\mathrm{G}$ as a third group, and $\mathrm{D}$ and $\mathrm{H}$ as the oldest group. The model could then calculate redistribution among the old, the young and middle generations, but not between rich and poor. Neither of these approaches captures the fundamental distinction between the two types of individuals in this economy" (Fullerton and Rogers, 1993:4).

The distribution of wealth in South Africa is such that three distinct groups of wealth owners can be identified, namely, a rich business class that owns most of the capital in the economy; a middle group employed by the capital owners and who earns good salaries; and a large poor group that lives on or below the poverty line.

The distribution of wealth in South Africa has furthermore probably been stationary for a century or more and some long run policy measures might be necessary to alter the distribution. It is therefore necessary to study the three groups in a life-cycle setting, and we combine the two approaches mentioned by Fullerton and Rogers '...to capture the fundamental distinction between rich and poor individuals classified on the basis of lifetime income' (Fullerton and Rogers, 1993:4).

\section{The model}

The model is a general equilibrium simulation model that encompasses all major South African taxes. Consumers are identified by both age and lifetime income and wealth. There is one industry with constant returns to scale technology and two inputs, labour and capital. It is a life-cycle model in which each individual from each of the three groups receives a particular inheritance, works in every period to receive a wage, earns income from capital which is made available to the production sector, and makes a bequest at the end of his life. Each individual pays taxes, and the poor group receives a government transfer in each period. Each individual plans an entire lifetime of commodity demands, savings, and bequests in the beginning of his life. The effects of tax changes on each economic decision through time are simulated in the model, while new savings, capital stocks, outputs, and prices are calculated. Since the effects on consumers from all age groups and for all periods are derived in the simulation process, the change in economic welfare for groups ranging from the lowest lifetime income to the highest can also be calculated.

Utility-maximising behaviour is assumed in order to solve for commodity demand and saving as functions of income and prices. Second, a production function is specified and cost-minimising behaviour in a competitive market is assumed to solve for each factor demand as a function of factor prices. Third, the net impact of taxes when these behaviours are considered simultaneously is sought. To capture all these features in one model, use is made of a general equilibrium model. 
The model is an overlapping generations model, in which each generation lives for 55 years - eleven periods of five years each. At any point in time therefore, there exist eleven generations: one young, one old, and nine in between. Auerbach and Kotlikoff (1987) also developed a 55-year life cycle model to study dynamic fiscal policy, but they had 55 periods of one year each - a much larger model, although they only have one representative group. We are introducing three groups differing with respect to affluence, following Fullerton and Rogers, who model groups from twelve different income categories.

The eleven generations come from three groups: a rich group, a middle class, and a poor group. The rich group consists of the top $5 \%$ of each generation, the middle class of the next $30 \%$, and the poor make up the rest. In each period there are 33 consumer units operating in the model: eleven generations for each of the three groups.

\subsection{Consumer behaviour}

It is assumed that consumers have perfect foresight with respect to prices and interest rates in all future periods. After calculating the present value of potential lifetime earnings, consumers make intertemporal decisions about present and future consumption and saving. Their endowment consists of an initial inheritance received and periodical income from labour and capital. It is supplemented by government transfers (for the poor group), discounted at the after-tax interest rate and reduced by taxes, and a bequest made at the end of their lives. It has been argued that life cycle saving by itself may only explain about half of the observed capital stock (Kotlikoff and Summers, 1981). This is probably especially true in South Africa where the wealth distribution has been maintained for prolonged periods of time through large bequests being passed on from generation to generation. In the model the bequest given by an individual is assumed to be a predetermined multiple of his inheritance, in order to achieve a steady state growth rate.

Part of the capital stock is therefore attributable to the fact that individuals receive exogenous inheritances and are required to leave comparable bequests at the end of life. Incidence results depend on the differences in these inheritances among groups.

\subsection{Producer behaviour}

On the production side only one commodity is produced according to a constant returns to scale technology, using two factors of production: capital, and labour. One could have a third factor, namely, entrepreneurship, to distinguish between the type of labour income that the rich gets, and that of the other groups. Entrepreneurship would serve as "educated labour", and earn a higher income. By giving individuals from the various groups different amounts of labour, however, each of the three groups has its own level of labour supply, instead of only having two types of labour by distinguishing between the rich and the rest. This approach 
was also followed by both Auerbach and Kotlikoff (1987:11), and Fullerton and Rogers (1993:71), who gave different age groups different amounts of labour.

The production function has the simple Cobb-Douglas form. In each period competitive firms determine the factor prices of labour and capital from the respective marginal products. Indirect factor demand functions are the results of this process, which give factor prices in each period as a function of capital and labour demanded.

\subsection{Government behaviour}

The government in the model has as its primary concern the redistribution of wealth from the richer groups to the poor, and uses fiscal policy to accomplish this goal. The government starts with a tax structure similar to the current South African situation and then applies some policy changes. The changes modelled are (1) an increase in the tax on capital income to the two affluent groups, (2) the implementation of an estate tax, and (3) an increase in the sales tax rate. All the policy changes are modelled with and without an accompanying proportional decrease in the tax on the labour income of all three groups ${ }^{1}$. The adjustment in the wage tax is done to capture the pure effect of the tax change, i.e., to keep government revenues constant. The government gives their receipts back to the poor group in the form of transfer payments. Two main scenarios are modelled: one where the consumers do not know of the government's policy change in advance, and the other where the consumers know about the planned change, one period in advance.

\section{$2.4 \quad$ A 51-Period General Equilibrium Model with eleven overlapping generations and three consumer groups}

\subsubsection{The demand side}

At any given point in time, there are eleven generations of individuals alive in each group. In Table 1 below 15 generations are shown in 25 periods to give an indication of which overlapping generations are alive in each period. An individual from generation 12 is young (y) in period 12 and old (o) in period 22. Any generation $i$ is young in period $i$, and old in period $i+10$. In a specific period, e.g. period 14, generations 4 through 14 are alive; generation 14 is young and generation 4 old. In any period $t$, for $t$ greater than 10 , the generations alive are generations $\mathrm{t}-10$ through $\mathrm{t}$. Generation 1 only becomes old in period 11 , so that the first ten periods contain generations older than generation 1 . They are defined to be "unknown." The model below covers 51 generations and 51 periods, with periods 11 through 41 forming the core of the model, covering generations from the time that they are young until they are old.

\footnotetext{
${ }^{1}$ The tax rates on labour income are decreased by the same amount for all three groups until government revenues reach the steady state levels.
} 
Table 1: Overlapping generations for 25 periods

\begin{tabular}{|c|c|c|c|c|c|c|c|c|c|c|c|c|c|c|c|}
\hline & \multicolumn{15}{|c|}{ Generations } \\
\hline Period & 1 & 2 & 3 & 4 & 5 & 6 & 7 & 8 & 9 & 10 & 11 & 12 & 13 & 14 & 15 \\
\hline 1 & $y$ & & & & & & & & & & & & & & \\
\hline 2 & & y & & & & & & & & & & & & & \\
\hline 3 & & & $\mathbf{Y}$ & & & & & & & & & & & & \\
\hline 4 & & & & y & & & & & & & & & & & \\
\hline 5 & & & & & y & & & & & & & & & & \\
\hline & Ene & $y=$ & $y=$ & $=$ & & & & & & & & & & & \\
\hline 6 & 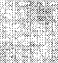 & $=$ & & 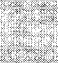 & 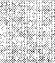 & $y$ & & & & & & & & & \\
\hline 7 & & $\sqrt{7}$ & 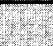 & 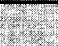 & $\sqrt{5}$ & 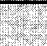 & $\mathrm{Y}$ & & & & & & & & \\
\hline 8 & & $x^{2}$ & & & & 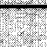 & 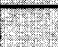 & y & & & & & & & \\
\hline 9 & & $=$ & $y$ & & & $\overline{2}$ & & 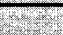 & $y$ & & & & & & \\
\hline & $y=$ & 5 & $=8$ & 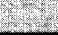 & $y=$ & 2 & ese & bet & 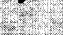 & & & & & & \\
\hline 10 & & $y^{2}$ & & 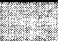 & $\sqrt{7}$ & & $\sqrt{3}$ & 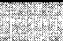 & 8 & $y$ & & & & & \\
\hline & 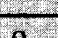 & $\bar{c}$ & $=$ & & & $=$ & & & & & $\%$ & & & & \\
\hline 11 & 8 & $=1$ & $=$ & 8 & $=3$ & $4=$ & 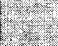 & & & & $y$ & & & & \\
\hline 12 & & o & 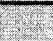 & 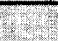 & 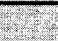 & $\sqrt{3}$ & $\bar{x}$ & & $\sqrt{7}$ & 5 & 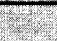 & y & & & \\
\hline 13 & & & o & & & $=$ & & & & & & & & & \\
\hline & & & a & 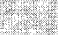 & res & 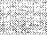 & we & & 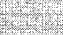 & Wy & 25 & $=0$ & $y=$ & & \\
\hline 14 & & & & 0 & $m a$ & 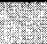 & tete & & 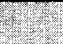 & 5 & te & 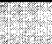 & 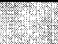 & $y$ & \\
\hline 15 & & & & & 0 & th & & SEnt & 5 & -7 & E- & (2) & 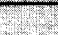 & 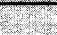 & y \\
\hline & & & & & & & 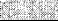 & ges & & & $=$ & & & & \\
\hline 16 & & & & & & 0 & & $E=x^{2}$ & & 7x & & 1.5 & & se & \\
\hline 17 & & & & & & & 0 & 7 & 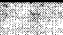 & 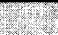 & to & sing & 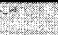 & 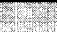 & 2 \\
\hline & & & & & & & $t e$ & $y=$ & $y=$ & 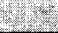 & 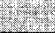 & erie & 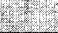 & & \\
\hline 18 & & & & & & & & 0 & $=$ & (n) & (x) & $5=1$ & 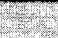 & tren & 5 \\
\hline & & & & & & & & & & & & & & & \\
\hline 19 & & & & & & & & & 0 & $=2$ & 5 & Fin & & $e^{x}=$ & \\
\hline 20 & & & & & & & & & & 0 & 드. & 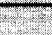 & 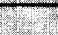 & $y=$ & ? \\
\hline & & & & & & & & & & $x=\frac{1}{2}$ & $x^{2}$ & min & 3 & $\Rightarrow$ & $=0$ \\
\hline 21 & & & & & & & & & & & 0 & $\bar{x}$ & $x=0$ & aly & 5 \\
\hline & & & & & & & & & & & & & & & \\
\hline 22 & & & & & & & & & & & & 0 & $x^{2}=7$ & & \\
\hline 23 & & & & & & & & & & & & & 0 & $=2=$ & \\
\hline & & & & & & & & & & & & & 0 & $=$ & \\
\hline 24 & & & & & & & & & & & & & & 0 & 5 \\
\hline 25 & & & & & & & & & & & & & & & 0 \\
\hline
\end{tabular}


A representative consumer from generation $i(i=11,12, \ldots, 41)$ and group $j(j=1,2,3)$ maximises his lifetime utility

$$
\mathrm{U}_{\mathrm{ij}}=\left(\sum_{\mathrm{t}=1}^{11} \mathrm{a}_{\mathrm{t}}^{1+\delta} \mathrm{C}_{\mathrm{ijt}}^{-\delta}\right)^{-\frac{1}{\delta}}
$$

subject to a lifetime budget constraint. This is a CES-type intertemporal utility function where the weighting parameter, $a_{t}$, reflects the consumer's subjective discount rate (Fullerton and Rogers, 1993:145).

In the model the same utility function is used for all three groups, that is, for everyone in the model. The reason for using the same utility function for all is that it seems arbitrary to assume that even if the poor were to receive additional wealth, they would still consume as if they were poor (Fullerton and Rogers, 1993:30).

The lifetime budget constraint is derived from eleven annual budget constraints:

$$
\begin{aligned}
& C_{i j 1}^{i}+S_{i j 1}=\left(1+r_{i}\right) I_{i j}+w_{i}^{\prime} L_{i j}+g_{1}=\left(1+r_{1}^{\prime}\right) I_{i j}+Y_{i j 1} \\
& C_{i j 2}+S_{i j 2}=\left(1+r_{2}^{\prime}\right) S_{i j 1}+w_{2}^{\prime} L_{i j}+g_{2}=\left(1+r_{2}^{\prime}\right) S_{i j 1}+Y_{i j 2} \\
& C_{i j 3}^{\prime}+S_{i j 3}=\left(1+r_{3}^{\prime}\right) S_{i j 2}+Y_{i j 3} \\
& C_{i j 10}^{\prime}+S_{i j 10}=\left(1+r_{10}^{\prime}\right) S_{i j 9}+Y_{i j 10} \\
& C_{i j 11}+B_{i j}\left(1+t_{E}\right)=\left(1+r_{11}^{\prime}\right) S_{i j 10}+Y_{i j 11},
\end{aligned}
$$

with $\mathrm{C}_{\mathrm{ijt}}=\mathrm{C}_{\mathrm{ijt}}\left(1+\mathrm{t}_{\mathrm{C}}\right)$, and $\mathrm{C}_{\mathrm{ijt}}$ the amount of the single commodity in the economy consumed by a consumer from generation $i$ and group $j$ in period $t$; $\mathrm{w}_{t}^{\prime}$ the after-tax price of labour in period $t\left(=\mathrm{w}_{t}\left(1-\mathrm{t}_{\mathrm{L}}\right)\right)$;

$\mathrm{L}_{\mathrm{ij}}$ the labour supplied by a consumer from generation $\mathrm{i}$ and group $\mathrm{j}$; $\mathrm{I}_{\mathrm{ij}}$ the amount inherited by consumer $\mathrm{ij}$;

$\mathrm{S}_{\mathrm{ijt}}$ the amount saved by him in period $\mathrm{t}$;

$B_{i j}$ the bequest made by consumer ij at the end of his life;

$r_{t}^{\prime}$ the after-tax rate of return on savings in period $t\left(=r_{t}\left(1-t_{K}\right)\right)$;

$\mathrm{g}_{\mathrm{t}}$ the government transfers received by each poor individual during period $t$;

$t_{C}, t_{L}, t_{K}$ and $t_{E}$ the consumption, wage, capital income, and estate tax rates respectively, and $Y_{\mathrm{ijt}}=\mathrm{w}_{\mathrm{t}}^{\prime} \mathrm{L}_{\mathrm{ij}}+\mathrm{g}_{\mathrm{t}}$.

A consumer from generation $i$ and group $j$ receives an inheritance $I_{i j}$ at the beginning of his life which he makes available to the production sector, and he earns a return of $\mathrm{r}_{\mathrm{t}} \mathrm{I}_{\mathrm{ij}}$ on it. During all the periods after his first he also earns returns on his savings from the respective previous periods; savings which are also made available to the production sector. He furthermore earns labour income $w_{t} L_{i j}$ during each period t that he is alive, which is added to his income from capital. At the end of the eleventh and last period the consumer leaves a bequest for the new young generation. This bequest will only become available as part of the capital stock when the new generation makes it available as their inheritance. 
The eleven annual budget constraints above can be substituted into one equation, which serves as the lifetime budget constraint:

$$
\begin{aligned}
& C_{\mathrm{ij} 11}^{\mathrm{i}}+\sum_{\mathrm{t}=1}^{10} \mathrm{C}_{\mathrm{ijt}}\left(\prod_{\mathrm{s}=\mathrm{t}+1}^{11}\left(1+\mathrm{r}_{\mathrm{s}}^{\prime}\right)\right)=\mathrm{Y}_{\mathrm{ij}}=\mathrm{I}_{\mathrm{ij}}\left(\prod_{\mathrm{s}=1}^{11}\left(1+\mathrm{r}_{\mathrm{s}}^{\prime}\right)-\mathrm{B}_{\mathrm{ij}}\left(1+\mathrm{t}_{\mathrm{E}}\right)\right. \\
& +\mathrm{Y}_{\mathrm{ij} 11}+\sum_{\mathrm{t}=1}^{10} \mathrm{Y}_{\mathrm{ijt}}\left(\prod_{\mathrm{s}=\mathrm{t}+1}^{11}\left(1+\mathrm{r}_{\mathrm{s}}^{\prime}\right)\right)
\end{aligned}
$$

with $\mathrm{Y}_{\mathrm{ij}}$ the lifetime resources available to consumer $\mathrm{ij}$.

The outcomes of the utility maximisation process are the individual commodity demand equations for eleven periods:

$$
\begin{aligned}
C_{i j 1} & =\frac{a_{1} Y_{i j}}{\sum_{t=1}^{11} a_{t} p_{t}\left(\frac{p_{1}}{p_{t}}\right) \frac{1}{1+\delta}} \quad \text { for } t=1, \ldots, 10 \\
C_{i j t} & =\frac{a_{t}}{a_{1}}\left(\frac{p_{1}}{p_{t}}\right)^{\frac{1}{1+\delta}} C_{i}
\end{aligned}
$$

with $\mathrm{p}_{\mathrm{t}}=\prod_{\mathrm{s}=\mathrm{t}+\mathrm{l}}^{11}\left(1+\mathrm{r}_{\mathrm{s}}^{\mathrm{s}}\right)$.

Each consumer may spend his lifetime income over the period of his life as he chooses. He can, therefore, save or borrow in every period. "Saving" in the last period is nothing but leaving a bequest to the next generation. The representative consumer has the following ten saving (or borrowing) functions in his first ten periods:

$$
\begin{aligned}
& S_{i j 1}=\left(1+r_{1}\right) I_{i j}+Y_{i j 1}-C_{i j 1} \\
& S_{i j t}=\left(1+r_{t}^{\prime}\right) S_{i j t-1}+Y_{i j t}-C_{i j t}, t=2, \ldots, 10 .
\end{aligned}
$$

The contribution to the capital stock of the economy by the consumer during any period $t$, is his saving from the previous period, except for the first period, when he makes his inheritance available for production purposes. Since there are eleven generations alive for each of three groups in the economy, there are 33 consumer groups contributing to the capital stock in each period. The capital stock in a period $t$ is the sum of inheritances by the young from all groups of generation $t$, plus the savings of the ten older generations from all three groups:

$$
\mathrm{Ks}_{\mathrm{t}}=\sum_{\mathrm{j}=1}^{3} \mathrm{I}_{\mathrm{ij}}+\sum_{\mathrm{j}=1 \mathrm{i}=\mathrm{t}-1}^{3} \mathrm{~S}_{\mathrm{ijt}}^{\mathrm{t}-10}
$$

\subsubsection{The supply side}

This model has production in 51 periods - 41 overlapping generations are modelled, each alive for eleven periods. There is one commodity, $\mathrm{X}$, that is 
produced by competitive firms. Two factors of production are used: capital, $\mathrm{K}$, and labour, $\mathrm{L}$. The two factor prices are $\mathrm{r}$ and $\mathrm{w}$ respectively.

Although there is a single homogeneous labour input, workers from different groups are assumed to differ in their skill levels; that is, some workers provide more of the homogeneous labour input per unit of time than do others. The situation in South Africa is such that the affluent whites mainly constitute the skilled labour force while the poor black majority constitutes the unskilled labour force. The model is constructed in such a way that each individual owns the same quality of labour services, but that the quantities vary between the three groups.

A single commodity $X_{t}$ is produced at the end of each period $t$ by competitive firms using capital, $K_{t}$ and labour $L_{t}$ in production. Firms produce according to a CobbDouglas production function with constant returns to scale:

$\mathrm{X}_{\mathrm{t}}=\mathrm{AK}_{\mathrm{t}}^{\mathrm{c}} \mathrm{L}_{\mathrm{t}}^{\mathrm{d}}$, with $\mathrm{c}+\mathrm{d}=1$.

Cost minimising by representative firms in the economy implies the following expressions relating factor demands to factor returns for all periods in the model:

$r_{t}=c A\left(L_{t} / K_{t}\right)^{d}$, and

$\mathrm{w}_{\mathrm{t}}=\mathrm{dA}\left(\mathrm{K}_{\mathrm{t}} / \mathrm{L}_{\mathrm{t}}\right)^{\mathrm{c}}$.

\subsubsection{The role of government in the overlapping generations model}

Five different taxes have already been introduced above, namely, a sales tax, a wage tax, a capital income tax, a wealth tax, and an estate tax. All of these taxes are not levied simultaneously during the simulations of the model below, but it is convenient to construct the model in such a way that it would provide for all possible taxes from the outset. If a certain tax is not levied with some combination of policy measures by the government, then the particular tax rates are set equal to zero.

The costless government in this model simply returns its tax revenue in the form of equal transfers to all the consumers from the poor group, and does not use its receipts to buy factors of production nor final goods.

The total revenues collected by the government from the three groups in any period $t$ are the sum of revenues from (1) the tax on capital income from generation t's inheritance and the ten older generations' savings:

$\sum_{\mathrm{j}=1}^{3}\left(\mathrm{r}_{\mathrm{t}} \mathrm{t}_{\mathrm{K}}\right)\left(\mathrm{I}_{\mathrm{tj}}+\sum_{\mathrm{i}=\mathrm{t}-10}^{\mathrm{t}-1} \mathrm{~S}_{\mathrm{ijt}}\right)$

(2) the sales tax on eleven generations' consumption:

$\sum_{j=1}^{3} \sum_{i=t-10}^{t} t_{C} C_{i j t}$ 
(3) the wage tax from eleven generations' labour supply:

$\sum_{j=1}^{3} \sum_{i=t-10}^{t} w_{t} t_{L} L_{i j t}$ and

(4) the estate tax from the bequests left by generation t-10:

$\sum_{j=1}^{3} t_{E} B_{j t-10}$

The sum of government revenues are shown in this order here:

$$
G_{t}=\sum_{j=1}^{3}\left(\left(r_{t} t_{K}\right)\left(I_{t j}+\sum_{i=t-10}^{t-1} S_{i j t}\right)+\sum_{i=t-10}^{t}\left(t_{C} C_{i j t}+w_{t} t_{L} L_{i j t}\right)+t_{E} B_{t-10}\right)
$$

\subsubsection{Equilibrium}

There are a total of three markets in each period: the commodity market, the capital market and the labour market. The conditions for equilibrium are that the factor demands for capital and labour equal factor supplies in each period. Since there is only one commodity in this economy, its price serves as the numeraire, and by Walras' Law the commodity market will automatically clear if both the factor markets clear. The indirect factor demand functions from equation (7) are $\mathrm{r}_{\mathrm{t}}=$ $\mathrm{cA}\left(\mathrm{L}_{\mathrm{t}} / \mathrm{K}_{\mathrm{t}}\right)^{\mathrm{d}}$, and $\mathrm{w}_{\mathrm{t}}=\mathrm{dA}\left(\mathrm{K}_{\mathrm{t}} / \mathrm{L}_{\mathrm{t}}\right)^{\mathrm{c}}$.

The capital supply function from equation (5) is

$$
\mathrm{Ks}_{\mathrm{t}}=\sum_{\mathrm{j}=1}^{3} \mathrm{I}_{\mathrm{tj}}+\sum_{\mathrm{j}=1}^{3} \sum_{\mathrm{i}=\mathrm{t}-1}^{\mathrm{t}-10} \mathrm{~S}_{\mathrm{ijt}}
$$

while the total labour supplied in any period $t$ is the sum of labour supplied by the three groups and eleven generations alive in period $t$ :

$$
\mathrm{Ls}_{\mathrm{t}}=\sum_{\mathrm{j}=1}^{3} \sum_{\mathrm{i}=\mathrm{t}}^{\mathrm{t}-10} \mathrm{Ls}_{\mathrm{ijt}} \text {. }
$$

Equilibrium in the factor markets can now be modelled by setting demand equal to supply in each period, i.e., by changing the indirect factor demand functions to the following:

$$
\mathrm{r}_{\mathrm{t}}=\mathrm{cA}\left(\mathrm{Ls}_{\mathrm{t}} / \mathrm{Ks}_{\mathrm{t}}\right)^{\mathrm{d}} \text {, and } \quad \mathrm{w}_{\mathrm{t}}=\mathrm{dA}\left(\mathrm{Ks}_{\mathrm{t}} / \mathrm{Ls}_{\mathrm{t}}\right)^{\mathrm{c}} .
$$

The commodity demand functions for some generation $\mathrm{i}$, and group $\mathrm{j}$, who are alive from period $s$ to $s+10$, were given in equation (3): 
$C_{i j s}=\frac{a_{s} Y_{i j}}{\sum_{t=s}^{s+10} a_{t} p_{t}\left(\frac{p_{s}}{p_{t}}\right) \frac{1}{1+\delta}} \quad$ for $j=1, . ., 3$

$C_{i j t}=\frac{a_{t}}{a_{s}}\left(\frac{p_{s}}{p_{t}}\right) \frac{1}{1+\delta} C_{i j s}^{i s} \quad$ for $\mathrm{t}=\mathrm{s}+1, . ., s+10$

with $Y_{i j}=I_{i j}\left(\prod_{s=1}^{11}\left(1+r_{s}^{\prime}\right)-B_{i j}\left(1+t_{E}\right)+Y_{i j 11}+\sum_{t=1}^{10} Y_{i j t}\left(\prod_{s=t+1}^{11}\left(1+r_{s}^{\prime}\right)\right)\right.$.

$\mathrm{Y}_{\mathrm{ijt}}$ consists of wage income and government transfers. Total commodity demand in any period $t$ will be

$$
\mathrm{C}_{\mathrm{t}}=\sum_{\mathrm{j}=1}^{3} \sum_{\mathrm{i}=1}^{11} \mathrm{C}_{\mathrm{ijt}} \text {. }
$$

Since the production function exhibits constant returns to scale, firms produce exactly the quantity demanded by the consumers. In any

period, $t$, the total quantity supplied, $X_{t}$, will be equal to quantity demanded:

$$
X_{t}=\sum_{j=1}^{3} \sum_{i=t}^{t-10} C_{i j t}+\sum_{j=1}^{3}\left(\sum_{i=t}^{t-9} S_{i j t}+B_{t-10, j}-\sum_{i=t-1}^{t-10} S_{i j t-1}\right)
$$

Since there is no money in this model, saving is defined in terms of the single commodity produced here. Production is therefore a sum of consumption and saving demand in any period, minus savings brought over from previous periods.

The government's budget is balanced in each period. Total revenues are equal to total taxes in each period:

$$
\mathrm{G}_{\mathrm{t}}=\sum_{\mathrm{j}=1}^{3}\left(\left(\mathrm{r}_{\mathrm{t}} \mathrm{t}_{\mathrm{K}}\right)\left(\mathrm{I}_{\mathrm{tj}}+\sum_{\mathrm{i}=\mathrm{t}-10}^{\mathrm{t}-1} \mathrm{~S}_{\mathrm{ijt}}\right)+\sum_{\mathrm{i}=\mathrm{t}-10}^{\mathrm{t}}\left(\mathrm{t}_{\mathrm{C}} \mathrm{C}_{\mathrm{ijt}}+\mathrm{w}_{\mathrm{t}} \mathrm{t}_{\mathrm{L}} \mathrm{L}_{\mathrm{ijt}}\right)+\mathrm{t}_{\mathrm{E}} \mathrm{B}_{\mathrm{t}-10}\right)
$$

\subsubsection{The steady state}

If the capital stock and labour supply grow at the same rate, it follows from equation (7) that factor prices will remain constant over time, since factor prices are functions of the ratio of capital to labour in each period. If capital and labour grow at the same rate, then the assumption of constant returns to scale in the CobbDouglas production function in equation (6) results in production growth at the same rate as the factors.

Consumption by generation $i$ in group $j$ is a simple function of their lifetime resources, which in turn is a linear function of (i) the inheritance they received, (ii) transfers they receive from the government, (iii) their fixed labour supply in each period, and (iv) the bequest that they leave behind. Consumption by the next 
generation in group $\mathrm{j}$ will be five per cent larger than that of generation $\mathrm{i}$, if their inheritance, labour supply, and the bequest they make all are five per cent larger.

Since the South African economy has grown at an average rate of one per cent per annum for the last 20 years, a steady state growth rate of five per cent per period is modelled. Sufficient assumptions for a steady state growth rate of five per cent to be obtained in the model, are that (i) the inheritances which generations receive grow at five per cent from generation to generation, (ii) the labour supplied grow at five per cent from generation to generation, and (iii) the bequests made grow at five per cent from generation to generation. If these conditions hold, the capital stock will also grow at the same rate.

\subsection{The welfare effects of a policy change}

The government in the general equilibrium model has as a final goal the redistribution of wealth. It is necessary to calculate the differences in welfare between the before-tax and after-tax steady states in order to make conclusions about the effectiveness of the redistribution policies. The measure of welfare differences that $I$ use is the equivalent percentage increase in lifetime resources needed in the original steady state to produce an individual's realised level of utility under the various redistribution policies.

According to Fullerton and Rogers, "computing lifetime tax incidence is a straightforward task.....within the lifetime model." (Fullerton and Rogers, 1993:66). They use a simple CES lifetime utility function, and find the equivalent variation to be

$E V \quad=\left(U^{n}-U^{o}\right) P_{U}^{o}$,

where $\mathrm{U}^{\mathrm{n}}$ is the new lifetime utility level, $\mathrm{U}^{\mathrm{o}}$ is the old utility level, and $\mathrm{P}_{\mathrm{U}}^{\mathrm{o}}$ the "lifetime price index" for utility (Fullerton and Rogers, 1993:67). Since the expenditure function takes on the form, $\mathrm{E}=\mathrm{P}_{\mathrm{U}} \mathrm{U}$, the equivalent percentage change in lifetime resources must be

$$
\begin{aligned}
E V / E^{o} & =\left(U^{n}-U^{o}\right) P^{o}{ }_{U} / E^{o} \\
& =\left(U^{n}-U^{o}\right) P^{o}{ }_{U} / P^{o}{ }_{U}^{o} U^{o} \\
& =\left(U^{n}-U^{o}\right) / U^{o},
\end{aligned}
$$

which is merely the percentage change in lifetime utility.

\subsection{Calibrating the model}

The parameters of the multi-period general equilibrium model are chosen to resemble the South African situation in 1985. The ratios of wealth ownership from that study are used for the three groups in this model. To model the effects of a government policy change in 1995, or period 21, the capital stock and labour force values for South Africa in 1985 are used in period 19. (Each period is five years long). 
The factor elasticities for the Cobb-Douglas production function, $X=A K^{a} L^{b}$, were obtained from econometric estimation. The estimated values for $\mathrm{A}, \mathrm{a}$, and $\mathrm{b}$ are $\mathrm{A}=272.6, \mathrm{a}=0.427$ and $\mathrm{b}=0.573$. These values are very close to those found by the South African Reserve Bank in 1984, who found $a=0.42$ and $b=0.58$. (South African Reserve Bank, 1984).

The total capital stock is divided between the three groups according to the actual wealth distribution taken from Van Heerden (1996:286). The top 5\% of the population (the rich group in the model) own $27 \%$ of all wealth, the next $30 \%$ of the population (the middle class in the model) own $63 \%$, and the bottom $65 \%$ of the population (the poor group in the model) $10 \%$.

The number of employed persons in the South African labour force are used as the labour input in the production function of the model. The average wages for 1985 are used to determine the amount of labour owned by each group. The average wage of the poor group, for example, was $25 \%$ of the middle class wage, and less than $10 \%$ of the rich group's wages. For each unit of labour that the poor provide, the middle class provides 4 units and the rich 10. The labour force is divided between the three groups according to these ratios, such that the total gives the 1985 employment figures for South Africa.

The initial steady state growth rate is assumed to be $5 \%$ per period, or $1 \%$ per annum. Although the South African economy has grown at a rate of between 2 and 3 per cent during the past 100 years, the last 20 years have only seen an average growth of $1 \%$ per annum.

On the demand side we followed Fullerton and Rogers, as well as Auerbach and Kotlikoff with the calibration of the parameters. We set the rate of time preference equal to 0.005, after Fullerton and Rogers (1993:145), since We are using the same lifetime utility function that they use. They determine the intertemporal share parameters, $a_{t}$, from the CES utility function, according to

$$
a_{t}=[1 /(1+\delta)]^{t-1} / \sum_{s=1}^{11}[1 /(1+\delta)]^{s-1},
$$

where $\mathrm{T}=11$, and $\delta$ is the rate of time preference.

The intertemporal elasticity of substitution was set to 0.25 , which is the value estimated by Auerbach and Kotlikoff to be the average value found from various estimations of the intertemporal elasticity of substitution (1987:51).

A progressive income tax system is modelled by imposing the average South African income tax rates on the three groups which are imposed by the South African Receiver of Revenue. The lowest income tax bracket is used for the poor, i.e., an average income tax of $17 \%$. The average rates for the other two groups are $25 \%$ and $35 \%$. (Cronjé and Stack, 1992:534). A sales tax of $14 \%$ is also modelled to capture the South African situation. Government revenues in this model are given back to the poor consumers in each period. 
The Katz commission of inquiry into the South African tax system recommended an increase in the tax on capital income, as well as an increase in the estate tax rate, and a reduction in the wage tax rates. (RSA). We modelled a $10 \%$ increase in the tax on income from capital for the two richer groups, as well as an introduction of a $10 \%$ estate tax. Although the Katz commission did not recommend an increase in the sales tax rate, we model an increase to $20 \%$ to compare such a policy measure with the other two measures.

\section{Simulation results}

Three policy changes have been simulated; an increase in the tax rate on capital income for the Rich and Middle Class; the implementation of an estate tax, and an increase in the general sales tax. First, with a proportional adjustment in the wage tax such that total government revenues (and hence government transfers) do not change, and second, without an effort to keep government revenues the same revenues and therefore transfers will increase. We shall refer to the adjusted and the unadjusted cases.

The adjusted simulations are done so that the effects of a tax change are not mixed up with the effects of the change in government revenues and transfers. A similar "differential" incidence analysis was done by Fullerton and Rogers (1993:35), where the effects of various taxes were compared with those of a proportional tax that raised the same revenue. This approach is also relevant for redistribution policy, since it shows how tax reform can result in an improved distribution of wealth, without increasing the total tax burden on individuals.

\subsection{An increase in the capital income tax}

An increase in the tax on capital income without an adjustment in other tax rates raises the total revenues collected by the government. Since all revenues are given back to the consumers, their annual and lifetime incomes are affected, and therefore also consumption levels and saving. If the wage tax rates are adjusted proportionally until government revenues equal the steady state values, it becomes possible to isolate the effects of the increase in the capital income tax. (The results of the adjusted and unadjusted simulations are generally similar, and differ only in magnitude). The outcomes of an increase in the capital income tax are the following:

(1) The growth rate in the total capital stock drops dramatically in the period after the policy change. (The reason for not dropping in the period of change is that the capital stock in any period is made up of savings from the previous period). In the case of an unexpected policy change the growth rates are always below the steady state growth rate of $5 \%$ per period, while the levels of the capital stock also drop below the steady state levels in each period after the policy change.

(2) The total level of consumption increases for a number of periods and then drops below the steady state levels. When the economy returns to the 
steady state growth rates, the level of total consumption is lower than what it would be without the policy change.

The decomposition of total consumption into three parts according to the groups modelled renders interesting results. The most dramatic results are obtained when the policy change is unexpected, and unadjusted; i.e., when government revenues and transfers are allowed to increase with the implementation of a capital income tax. The rich group unambiguously consumes less after an increase in the tax on their capital income.

\subsection{The implementation of an Estate Tax}

The implementation of an estate tax has opposite effects on the final levels of the total capital stock and total consumption, than an increase in the capital income tax. Both the levels of the capital stock and consumption end up higher than what it would have been without the policy change. Consumption decreases initially for a number of periods, and then rises above the steady state levels where it remains. The model shows that the capital stock shoots up and remains above the steady state levels during all the periods after the policy change. The reason is that the model is constructed with the assumption that consumers leave a bequest which is a fixed multiple of their inheritance. If consumers get a one period in advance warning of the government's intention to implement an estate tax, the capital stock starts growing faster one period earlier, but returns to the steady state sooner.

The distribution of wealth does not improve unambiguously as with a capital income tax. While the richer two groups generally consume less after the implementation of an estate tax, all the generations in the poor group do not consume more than without the policy change. Since they are also subject to the estate tax, a few generations consume less soon after the policy change, while other generations' consumption decreases towards the end of their lives.

The poor group, who also pays the estate tax, has a general increase in consumption after the policy change, except for the group that is old at the time of the implementation of the tax, who has a 2,5 per cent decrease in consumption. The situation concerning the poor group would be worse if the government were to adjust the wage tax rate downwards until government revenues reaches the pre-tax levels. The oldest four generations would experience a drop in consumption due to the implementation of the estate tax, and only the fifth generation and beyond would experience increased consumption levels.

With the implementation of an estate tax, the equivalent variations for the rich and poor groups in the new steady state are zero and 2 per cent in the adjusted cases, and $-8,1$ per cent and 7 per cent if the government does not adjust the wage tax rates in order to keep its revenues constant. 
This redistribution policy is effective if the government does not adjust other taxes to bring government revenues in line with pre-tax levels. With an increase in the general sales tax, the equivalent variations for the rich and poor groups in the new steady state are 4,1 per cent and $-2,5$ per cent in the adjusted cases, and -5 per cent and 4 per cent if the government does not adjust the wage tax rates in order to keep its revenues constant. With an adjustment in the wage tax rates (downward), the rich group will be much better off than with no adjustment. In the latter case they pay an increased amount of sales tax together with the same income taxes as before. The poor group would like to see no adjustment in wage taxes, since they are the sole beneficiaries of a higher level of government transfers in that case. Although their wage taxes are also adjusted downward in the case of the adjusted policy change, the effect of smaller transfers are much stronger here, and the poor group will in fact be worse off than without the policy change, as shown by the line on the right. A one period in advance warning would again soften the blow of the policy change scenarios converge to the same levels in the long run.

With no adjustment in other taxes, both the total capital stock and total consumption in the economy decrease. With an increase in the sales tax rate, total consumption shoots up immediately after the policy change, but decreases to a new steady state level just below the old level. The poor class group's consumption increases, but is offset by decreases in the other two groups' consumption.

With the adjustment in the wage tax to keep government revenues unchanged, total consumption and the total capital stock increase in the new steady state, but at the expense of the poor group, whose consumption decreases quite dramatically. This policy change therefore either harms the poor group, or the economy as a whole.

\section{Conclusion}

In a developing country such as South Africa, tax policies which address the imbalance in the distribution of welfare, should be implemented with great care. Of special interest is the fact that the apparent preference by governments to implement taxes on capital income and indirect taxes, can be more harmful and ineffective than expected. The implementation of an estate tax, on the other hand, improves the distribution of wealth, with much more positive results. Such a form of taxation could result in a substantial improvement in the general level of wealth of the poor without jeopardising the growth potential of the economy. The results would be even less disruptive, should the government always announce this change in tax policy in advance.

\section{REFERENCES}

Auerbach, AJ and Kotlikoff, LJ (1987): Dynamic Fiscal Policy, Cambridge: Cambridge University Press.

Auerbach, AJ, Gokhale, J and Kotlikoff, LJ (1994): "Generational Accounting: A Meaningful Way to Evaluate Fiscal Policy", Journal of Economic Perspectives, 8(1), 73-94. 
Bradford, D (1986): Untangling the Income Tax, Cambridge: Harvard University Press.

Cronje, M and Stack, EM (1992): The Taxing of Individuals and Companies, Pretoria: Digma.

Fullerton, D and Rogers, DL (1993): Who Bears the Lifetime Tax Burden?, Washington D.C.: The Brookings Institution.

Gillis, M (ed.) (1989): Tax Reform in Developing Countries, Durham and London: Duke University Press.

Koffman, EB (1995): Turbo Pascal, New York: Addison-Wesley Publishing Co.

Kotlikoff, LJ and Summers, LH (1981): "The Role of Intergenerational Transfers in Capital Accumulation", Journal of Political Economy, 89(4), 706-732

McLure, CE, Mutti, J, Thuronyi, V and Zodrow, GR (1990). The Taxation of Income From Business and Capital in Colombia. Durham and London: Duke University Press.

Republic of South Africa (RSA), Budget review, Various editions.

Smith, RS (1993): Personal Wealth Taxation: Canadian Tax Policy in a Historical and an International Setting, Canadian Tax Paper \#97, Canadian Tax Foundation.

Tiebout, CM (1956): "A Pure Theory of Local Expenditures", Journal of Political Economy, 64 (October), 416-424.

Van Heerden, JH (1996): "The Distribution of Personal Wealth in South Africa", The South African Journal of Economics, 64(4), 278-292.

Zodrow, GR (1993): "Economic Analyses of Capital Gains Taxation: Realisations, Revenues, Efficiency and Equity": Tax Law Review, 48, 419-536. 